Original Research Article

\title{
Evaluation of knowledge of vitamin D aspects among pharmacy and engineering students in University of Sharjah, United Arab Emirates
}

\author{
Suleiman I. Sharif*, Salma Ibrahim, Asma Mohammad, \\ Ghazal Matini, Rawan S. Sharif
}

\begin{abstract}
Department of Pharmacy
Practice and

Pharmacotherapeutics, College

of Pharmacy, University of

Sharjah, United Arab Emirates
\end{abstract}

Received: 29 September 2019

Accepted: 11 November 2019

*Correspondence to:

Dr. Suleiman I. Sharif,

Email: sharifsi@sharjah.ac.ae

Copyright: (C) the author(s), publisher and licensee Medip Academy. This is an openaccess article distributed under the terms of the Creative Commons Attribution NonCommercial License, which permits unrestricted noncommercial use, distribution, and reproduction in any medium, provided the original work is properly cited.

\begin{abstract}
Background: Vitamin D plays a major role in health. Several health disorders have been associated with its deficiency. The objectives of this study were to evaluate the knowledge of and attitude towards vitamin D of pharmacy and engineering students in the University of Sharjah, United Arab Emirates.

Methods: A descriptive cross-sectional study was conducted during FebruaryApril, 2018. A 30 questions survey in English was designed, pre-validated and distributed to 250 students. The questionnaire was designed to evaluate and compare student's knowledge and awareness of vitamin D.

Results: 213 participants completed the survey producing a response rate of $85.2 \%$. The majority of students were Arabs, females and of age ranging 21-23 years. Almost all pharmacy students were familiar with many aspects of vitamin D. Unlike engineering $(66 ; 66.6 \%)$, most $(113 ; 99.1 \%)$ pharmacy students know the meaning of osteoporosis. Knowledge of pharmacy students on vitamin D was generally better than that of engineering students particularly with questions on technical parameters of vitamin D levels and dosage. Students who took vitamin D test were advised by a physician. Most of the students from both colleges have a positive attitude to receive information on vitamin $\mathrm{D}$ through brochures, lectures/seminars and workshops.

Conclusions: Awareness of non-health sciences and to some extent of pharmacy students seems to be inadequate and efforts are needed to increase awareness of the public in general of the importance of vitamin to health status.
\end{abstract}

Keywords: Knowledge, Attitude, Pharmacy, Engineering, Vitamin D, Deficiency

\section{INTRODUCTION}

One of the most important agents that affects the mineralization of the skeleton is vitamin D. ${ }^{1}$ Bone is a significant part of the skeletal muscles, which necessitates a balanced store of vitamin $\mathrm{D}$, phosphorus and calcium. ${ }^{2}$ Vitamin D can be attained in $10-20 \%$ from nutritional sources such as fatty fish (salmon, tuna, fish liver oils), beef liver, egg yolk and cheese and 80-90\% from sunlight. The role of vitamin $\mathrm{D}$ is important to the body as it affects the muscle strength, diabetes, certain cancers, blood pressure, psoriasis, immune system functioning and managing the cardiovascular disease. ${ }^{3-7}$ A natural recommended form of vitamin D is vitamin D3 known as cholecalciferol and obtained either from sunlight or supplements, by first hydroxylation in liver to $25(\mathrm{OH}) \mathrm{D}_{3}$, and a second hydroxylation in kidneys to form $1,25(\mathrm{OH})_{2}$ vitamin $\mathrm{D}_{3}$ which is considered the active form for biological action. Moreover, vitamin $\mathrm{D}_{3}$ is prescribed to increase the serum level since it has a lower affinity to binding proteins and has a rapid clearance. The best indicator of vitamin D store is the level of $25(\mathrm{OH})$ $\mathrm{D}_{3}$, identified as the main circulating form of vitamin $\mathrm{D}$ and has a half-life of about 2-3 weeks. ${ }^{6}$ Therefore, the 
recommended dietary allowance of vitamin $\mathrm{D}$ has been increased from 400 to 600 International units (IU) for those aged 1-70 years according to The Institute of Medicine in $2011 .^{8}$

Deficiency in vitamin D can be linked to many factors such as; race, old age, body mass index $>30 \mathrm{~kg} / \mathrm{m}^{2}$, reduced exercise (sedentary life), poor diet, insufficient sun exposure, diseases that affect the absorption of vitamin $\mathrm{D}$ and some drugs that interfere with vitamin $\mathrm{D}$ metabolism. ${ }^{9}$ Insufficient vitamin D intake leads to defective mineralization of skeleton, causing rickets in infancy, bone loss, osteomalacia, osteoporosis, hip fractures and cancer, type 1 diabetes, cardiovascular disease, depression and respiratory problems in adults. $^{10,11}$ Moreover, oral vitamin D supplement, increased UV light exposure and a better dietary intake will help exclude these problems and maintain the necessary amount of calcium in the blood. ${ }^{12,13}$

On the other hand, conditions in which there is increased concentration of $25(\mathrm{OH}) \mathrm{D}_{3}$ in the blood can lead to vitamin $\mathrm{D}$ toxicity and result in adverse systemic effects. Furthermore, acute or long term consumption of high amounts of vitamin D can also lead to imbalance in calcium metabolism. In addition, excessive use in treatment of hypoparathyroidism or secondary hyperparathyroidism of renal osteodystrophy will lead hyper-vitaminosis in adults. Consuming adult dose in children will also lead to toxicity. In contrast, it is customary to have a higher chance of vitamin D deficiency than toxicity. ${ }^{14}$

The present study was undertaken to assess the knowledge of health and non-health sciences students at the University of Sharjah, United Arab Emirates (UAE) of various aspects of vitamin D. Another objective of the study was to increase awareness of students to such an important health aspect and correct the misconception that people living in UAE are protected against vitamin D deficiency by the hot climate and the availability of sun light almost throughout the year.

\section{METHODS}

\section{Study population}

We used a descriptive cross-sectional study designed to survey students at health and non-health colleges of the University of Sharjah. The inclusion criteria were students of the last two years of study in a health (pharmacy) and non-health (engineering) colleges. Thus students approached were 4th and 5th year pharmacy students and 3rd and 4th engineering students. A total of 250 surveys were distributed.

\section{Questionnaire design, distribution and collection}

We used an anonymous questionnaire of 30 questions designed after reviewing earlier studies carried elsewhere.
The survey was written in English and was pre-piloted by distributing it to 6 participants including 3 students from each college to ensure face validity and to ensure that the questions are not vague or ambiguous. Comments and recommendations of those students were considered in the final version of the questionnaire but their responses were not included in the study. The questionnaire consisted of two sections covering demographic characteristics of the participants including the gender, age, college, year of study and ethnicity, the second section dealt with questions to assess the knowledge of participants of general as well as some technical information of vitamin $\mathrm{D}$. The questionnaire was distributed at the end of lectures and took on average 15 minutes to complete. The researchers explained the purpose of the study and participants were included in the study only after obtaining written informed consent. Students were assured by the researchers of the confidentiality of the collected data. The study was carried out during January to March, 2018.

\section{Statistical analysis}

We analyzed the collected data by using an acronym of statistical package for the social science (SPSS for windows, version 20). Chi-squared test was used to assess any significant difference among the student's responses with a significant level of $\mathrm{p}<0.05$. The data were analyzed and expressed as frequency and percentage of total students in each college. In some questions with more than one option, participants can select more than one answer, therefore the sum of percentages is not always $100 \%$.

\section{RESULTS}

Surveys returned complete counted to 213 producing a response rate of $85.2 \%$. Demographics of the participants are shown in Table 1. Almost similar numbers of pharmacy $(114 ; 53.5 \%)$ and engineering (99, 46.5\%) students participated in the study. About $50 \%$ of all participants where fourth year students. Most of the participants were Arabs (196; 92\%), females and 21 to 23 years old.

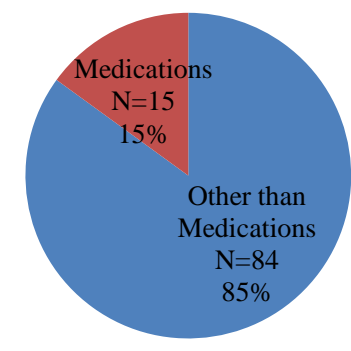

Figure 1: Response of engineering students regarding source of vitamin $D$. 
Table 1: Demographic characteristics of participants.

\begin{tabular}{|ll|}
\hline Demographic data & \begin{tabular}{l} 
Frequency $(\mathbf{n}=\mathbf{2 1 3})$ \\
\hline Gender
\end{tabular} \\
\hline Male & $13(6.1)$ \\
\hline Female & $200(93.9)$ \\
\hline Age & \\
\hline $18-20$ & $52(24.4)$ \\
\hline $21-23$ & $146(68.5)$ \\
\hline $24-26$ & $15(7)$ \\
\hline College & \\
\hline Pharmacy & $114(53.5)$ \\
\hline Engineering & $99(46.5)$ \\
\hline Year of study & \\
\hline Third & $52(24.4)$ \\
\hline Fourth & $108(50.7)$ \\
\hline Fifth & $53(24.9)$ \\
\hline Ethnicity & \\
\hline Arab & $196(92)$ \\
\hline Non-Arab & $17(8)$ \\
\hline
\end{tabular}

Table 2 show responses of students to questions examining their knowledge of vitamin D. The results in general indicate a higher level of knowledge among pharmacy than engineering students with regard to knowing vitamin D deficiency, its relation to calcium, its implication in various disease states, whether its levels are influenced by smoking and exercise and whether exercise helps in building new bone.

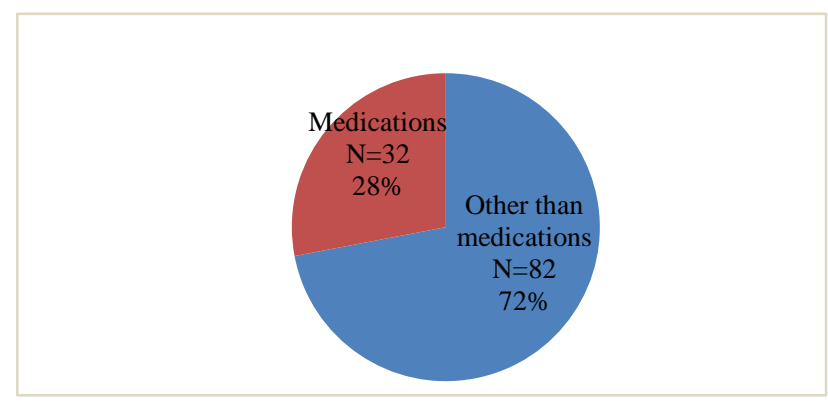

Figure 2: Response of pharmacy students regarding source of vitamin $D$.

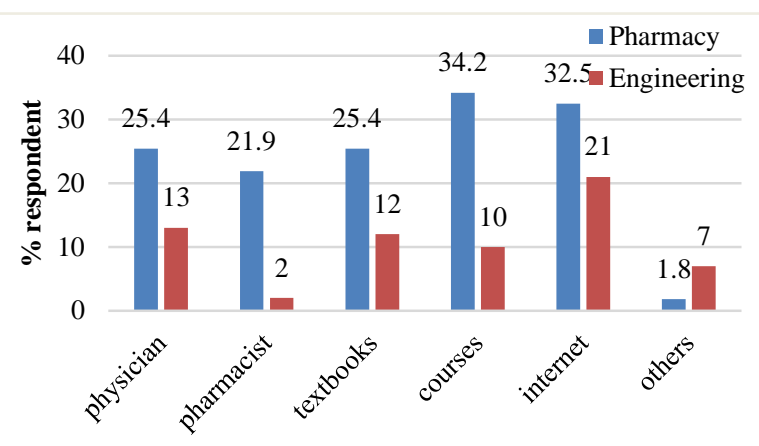

Figure 3: Various sources of participant's information about vitamin $\mathrm{D}$ deficiency.
Knowledge of engineering and pharmacy students on sources of vitamin D is shown in Figures 1 and 2.

Knowledge of both groups of students on serum levels of vitamin $\mathrm{D}$ that indicate insufficiency was rather poor, however, that of pharmacy students on dosage regimen was significantly more better than that of engineering students (Table 3).

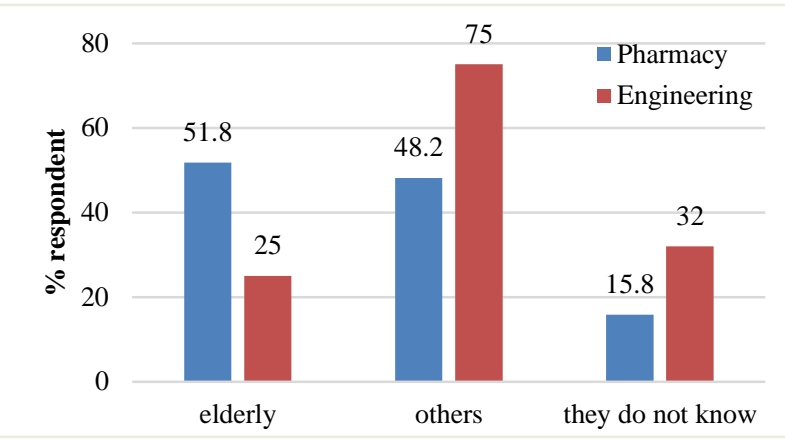

Figure 4: Response of participants to various categories of population that is at high risk of vitamin D deficiency.

This is also the case when it comes to student's opinion whether they have enough information on vitamin D. Various sources of information about vitamin deficiency and categorization by participants of population at risk of vitamin D deficiency are shown in Figures 3 and 4.

However, more engineering students prefer to receive informative brochures rather than attending seminars or lectures, and only a few of each group showed interest in participating in campaigns to increase awareness of public to vitamin D. Significant association ( $p$ 0.03$<0.001)$ was observed between older age groups $(21-23$ and 24-26) and general knowledge on vitamin D (Table 4).

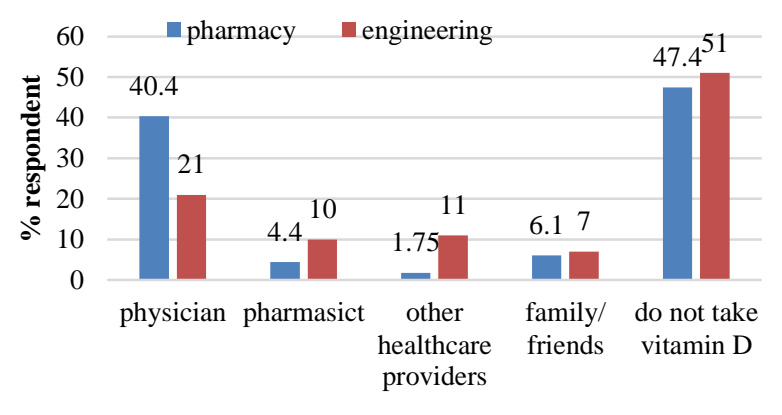

Figure 5: Responses of participants to who recommended the use of vitamin $D$ supplement.

Knowledge of serum levels that are indicative of vitamin $\mathrm{D}$ insufficiency was significantly poor among the group of 21-23 years range of age (Table 4). On the other hand, for dosage regimen, a weekly 50,000 IU of vitamin D for 8 weeks was selected by the youngest age group (18-20). 
Table 2: Comparison of knowledge of pharmacy and engineering students on vitamin D.

\begin{tabular}{|c|c|c|c|c|}
\hline \multirow{2}{*}{ Criteria } & \multicolumn{4}{|l|}{ Frequency $\mathbf{N}(\%)$} \\
\hline & Pharmacy $(n=114)$ & Engineering $(\mathbf{n}=99)$ & Total $(n=213)$ & *Chi-square test \\
\hline \multicolumn{5}{|c|}{ Do you know the importance of vitamin $D$ for the body? } \\
\hline Yes & $111(97.3)$ & $87(87.9)$ & $198(93)$ & \multirow{2}{*}{$<0.001$} \\
\hline No & $3(2.7)$ & $2(12.1)$ & $15(7)$ & \\
\hline \multicolumn{5}{|c|}{ Do you know about vitamin D deficiency? } \\
\hline Yes & $106(92.9)$ & $54(54.5)$ & $160(75.1)$ & \multirow{2}{*}{$<0.001$} \\
\hline No & $8(7)$ & $45(45.4)$ & $53(24.8)$ & \\
\hline \multicolumn{5}{|c|}{$\begin{array}{l}\text { Do you think that vitamin D deficiency is related to diseases like cardiovascular, diabetes, depression, } \\
\text { hypercholesterolemia, cancer, multiple sclerosis and respiratory disease? }\end{array}$} \\
\hline Yes & $73(64)$ & $52(52.5)$ & $125(58.7)$ & \multirow{2}{*}{0.06} \\
\hline No & $41(35.96)$ & $47(47.5)$ & $88(41.3)$ & \\
\hline \multicolumn{5}{|c|}{ Do you think calcium and vitamin $D$ are related? } \\
\hline Yes & $109(95.6)$ & $71(71.7)$ & $180(84.5)$ & \multirow{2}{*}{$<0.001$} \\
\hline No & $5(4.3)$ & $28(28.2)$ & $33(15.5)$ & \\
\hline \multicolumn{5}{|c|}{ Do you know what osteoporosis mean? } \\
\hline Yes & $113(99.1)$ & $33(33.3)$ & $146(68.5)$ & \multirow{2}{*}{$<0.001$} \\
\hline No & $1(0.87)$ & $66(66.6)$ & $67(31.5)$ & \\
\hline \multicolumn{5}{|c|}{ Do you think smoking affects vitamin $D$ and calcium levels? } \\
\hline Yes & $96(84.2)$ & $72(72.7)$ & $168(78.9)$ & \multirow{2}{*}{0.03} \\
\hline No & $18(15.7)$ & $27(27.2)$ & $45(21.1)$ & \\
\hline \multicolumn{5}{|c|}{ Do you think exercise affects vitamin D levels? } \\
\hline Yes & $78(68.4)$ & $52(52.5)$ & $130(61)$ & \multirow{2}{*}{0.01} \\
\hline No & $36(31.5)$ & $47(47.4)$ & $83(39)$ & \\
\hline \multicolumn{5}{|c|}{ Do you think exercise helps in building new bones? } \\
\hline Yes & $85(74.5)$ & $64(64.6)$ & $149(70)$ & \multirow{2}{*}{0.08} \\
\hline No & $29(25.4)$ & $35(35.3)$ & $64(30)$ & \\
\hline
\end{tabular}

*: Significance level at $\mathrm{p}<0.05$.

Table 3: Knowledge of participants on serum levels and recommended dosage of vitamin D.

\section{Questions}

Frequency N (\%)

$\begin{array}{lll}\begin{array}{l}\text { Pharmacy } \\ (n=114)\end{array} & \begin{array}{l}\text { Engineering } \\ (\mathbf{n}=99)\end{array} & \begin{array}{l}\text { Total } \\ (\mathbf{n}=213)\end{array}\end{array} *$ Chi-square test

Do you know what vitamin $D$ serum levels in an adult that indicate insufficiency?

\begin{tabular}{|llll}
\hline Insufficiency at 20-29 ng/ml, deficiency $\leq 20 \mathrm{ng} / \mathrm{ml}$ & $10(8.8)$ & $4(4)$ & $14(6.6)$ \\
\hline Insufficiency at 10-19 ng/ml; deficiency $\leq 15 \mathrm{ng} / \mathrm{ml}$ & $14(12.2)$ & $4(4)$ & $18(8.5)$ \\
\hline Insufficiency at 20-29 ng/ml; deficiency $\leq 30 \mathrm{ng} / \mathrm{ml}$ & $18(15.7)$ & $9(9.1)$ & $9(9.1)$ \\
\hline Insufficiency at 20-29 ng/ml; deficiency $\leq 10 \mathrm{ng} / \mathrm{ml}$ & $6(5.3)$ & $6(6.1)$ & $12(5.6)$ \\
\hline I do not know. & $66(57.8)$ & $76(76.7)$ & $99(46.5)$ \\
\hline Do you know what dose regimen of vitamin D recommended for treatment of vitamin D deficiency? \\
\hline 50,000 IU of vitamin D once a week for 6-8 weeks & $59(51.7)$ & $20(20.2)$ & $79(37.1)$ \\
\hline 60,000 IU once a week for 8 weeks & $3(2.6)$ & $6(6.1)$ & $9(4.2)$ \\
\hline 5000 IU once a week for 10 weeks & $15(13.1)$ & $5(5.1)$ & $20(9.4)$ \\
\hline 8000 IU/day for 6 months & $4(3.5)$ & $2(2)$ & $6(2.8)$ \\
\hline I do not know. & $33(28.9)$ & $66(66.6)$ & $99(46.5)$ \\
\hline Do you think you have enough information about Vitamin D? & & \\
\hline Yes & $54(47.3)$ & $23(23.2)$ & $77(36.2)$ \\
\hline No & $60(52.6)$ & $76(76.7)$ & $136(63.8)$ \\
\hline Would you like to: & & & \\
\hline Receive brochures of information on vitamin D & $60(52.6)$ & $70(70.7)$ & $130(61)$ \\
\hline Attend seminars/lectures on vitamin D and health & $30(26.3)$ & $20(20.2)$ & $50(23.5)$ \\
\hline $\begin{array}{l}\text { Actively participate in campaigns to increase public } \\
\text { awareness on the importance of vitamin D. }\end{array}$ & $24(21)$ & $9(9.1)$ & $33(15.5)$ \\
\hline
\end{tabular}


Table 4: Association of age of participants with their knowledge on vitamin D.

\begin{tabular}{|c|c|c|c|c|}
\hline \multirow{2}{*}{ Questions } & \multicolumn{4}{|c|}{ Age group (in years) $\mathbf{N}(\%)$} \\
\hline & 18-20 & 21-23 & 24-26 & *Chi-square test \\
\hline \multicolumn{5}{|c|}{ Do you know about vitamin D deficiency? } \\
\hline Yes & $33(63.5)$ & $115(78.8)$ & $13(86.7)$ & \multirow{2}{*}{0.03} \\
\hline No & $19(36.5)$ & $31(21.2)$ & $2(13.3)$ & \\
\hline \multicolumn{5}{|l|}{ Do you know what osteoporosis mean? } \\
\hline Yes & $24(46)$ & $112(76.7)$ & $10(66.6)$ & \multirow{2}{*}{$<0.001$} \\
\hline No & $28(54)$ & $34(23.2)$ & $2(13.3)$ & \\
\hline \multicolumn{5}{|c|}{ Do You think you have enough information about vitamin D? } \\
\hline Yes & $10(19.2)$ & $60(41.1)$ & $7(46.7)$ & \multirow{2}{*}{$<0.01$} \\
\hline No & $42(80.8)$ & $86(58.9)$ & $8(53.3)$ & \\
\hline \multicolumn{5}{|l|}{ Have you ever had a vitamin D test? } \\
\hline Yes & $19(36.5)$ & $89(61)$ & $10(66.6)$ & \multirow{2}{*}{$<0.01$} \\
\hline No & $33(63.5)$ & $57(39)$ & $5(33.4)$ & \\
\hline \multicolumn{5}{|c|}{ Did you ever take a vitamin D supplement? } \\
\hline Yes & $25(48)$ & $82(56)$ & $9(60)$ & \multirow{2}{*}{$<0.01$} \\
\hline No & $27(52)$ & $64(44)$ & $6(40)$ & \\
\hline \multicolumn{5}{|c|}{ Do you know what vitamin D serum levels in an adult that indicate insufficiency/deficiency: } \\
\hline Insufficiency at $20-29 \mathrm{ng} / \mathrm{ml}$ & $10(8.8)$ & $4(4)$ & $14(6.6)$ & \multirow{5}{*}{$<0.03$} \\
\hline $\begin{array}{l}\text { Insufficiency at } 10-19 \mathrm{ng} / \mathrm{ml} \text { deficiency } \\
\leq 15 \mathrm{ng} / \mathrm{ml}\end{array}$ & $14(12.2)$ & $4(4)$ & $18(8.5)$ & \\
\hline $\begin{array}{l}\text { Insufficiency at } 20-29 \mathrm{ng} / \mathrm{ml} \text { deficiency } \\
\leq 30 \mathrm{ng} / \mathrm{ml}\end{array}$ & $18(15.7)$ & $9(9.1)$ & $27(12.7)$ & \\
\hline $\begin{array}{l}\text { Insufficiency at } 20-29 \mathrm{ng} / \mathrm{ml} \text { deficiency } \\
\leq 10 \mathrm{ng} / \mathrm{ml}\end{array}$ & $6(5.3)$ & $6(6.1)$ & $12(5.6)$ & \\
\hline I do not know. & $66(57.8)$ & $76(76.7)$ & $99(46.5)$ & \\
\hline \multicolumn{5}{|c|}{ Do you know what dose regimen of vitamin D recommended for treatment of vitamin D deficiency? } \\
\hline $\begin{array}{l}50,000 \mathrm{IU} \text { of vitamin D once a week } \\
\text { for } 6-8 \text { weeks }\end{array}$ & $59(51.7)$ & $20(20.2)$ & $79(37.1)$ & \multirow{5}{*}{$<0.001$} \\
\hline 60,000 IU once a week for 8 weeks & $3(2.6)$ & $6(6.1)$ & $9(4.2)$ & \\
\hline 5000 IU once a week for 10 weeks & $15(13.1)$ & $5(5.1)$ & $20(9.4)$ & \\
\hline $8000 \mathrm{IU} /$ day for 6 months & $2(3.8)$ & $4(2.7)$ & 0 & \\
\hline I do not know. & $33(28.9)$ & $66(66.6)$ & $99(46.5)$ & \\
\hline
\end{tabular}

Pharmacy $(82,72 \%)$ and engineering $(84,85 \%)$ believed that the main source of vitamin $\mathrm{D}$ is other than medications. Pharmacy courses, the internet, physician and text books, and the pharmacist were the sources of information on vitamin D for pharmacy students. For engineering students, the order was the internet, physician, text books, courses and pharmacist. Slightly more than $50 \%$ of pharmacy students believe that elderly population are at higher risk of developing vitamin D deficiency than other sectors of the population, while $75 \%$ of engineering students believe that others are at higher risk than the elderly (Figure 4). For those participants who used vitamin D supplements (almost $50 \%$ of each group), the physician was the main healthcare provider who recommended such use (Figure 5 ). Two-thirds (60.7\%) of pharmacy and slightly less than $50 \%$ of engineering students took the screening test for vitamin D.

Percentages of pharmacy and engineering students who undergone vitamin D screening test are shown in Figure 6.

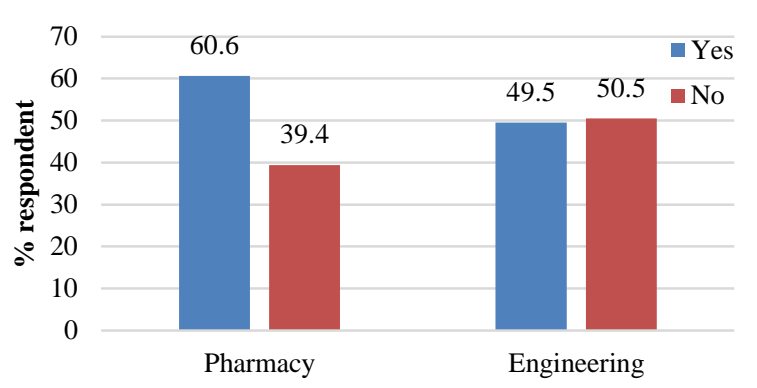

Figure 6: Percentages of students who undergone vitamin D screening test.

\section{DISCUSSION}

Both calcium and vitamin D are essentials for the health of bone and are therapeutically beneficial in preventing and treating disorders of bone loss whether due to vitamin D deficiency or conditions like age-induced 
osteoporosis. The risk of several diseases including cancer, autoimmune, infectious and cardiovascular diseases has been shown to be reduced by vitamin $\mathrm{D}{ }^{6}$ The International Osteoporosis Foundation in 2007 reported that despite the reasonable level of knowledge of patients of the role of calcium in bone, they are less aware of the benefits of vitamin D. ${ }^{14}$ It has been suggested that pharmacy students are assumed to have adequate knowledge of the various aspects of vitamin D as compared to students of the non-healthcare engineering college. In the present study, the majority of students were females mainly because in healthcare colleges in the university of Sharjah and despite the provision of coeducation, the number of male students is tremendously lower than females and this is a usual trend in all universities across UAE. It must be noted that in the college of engineering, males and females are taught separately and as the researchers who distributed and collected the questionnaire were females, they had access only to the female sections in the college of engineering which explains why all engineering students responding were females. Most participants were Arabs of age ranging from 21-23 years, a category that parallels their years of study. Knowledge of pharmacy students in the present study seems adequate and higher than that of engineering students and of their Bangladesh counterparts. $^{15}$ In the present study adequacy of information of pharmacy students is a consequence of their educational courses, which were their main source of information on vitamin D.

Our results on knowledge of some technical aspects, particularly those involving medical terms and dose regimen of vitamin $\mathrm{D}$ are consistent with the results reported for Canadian students where the level of knowledge of vitamin D of medical and health sciences students was better than that of students of science, arts, and social sciences. ${ }^{16}$

In the present study, the majority of both groups of students showed almost similar responses regarding the main sources of vitamin D where they selected the statement "other than medications". This is agreeable with the sun being a main source plus vitamin D-rich foods. It is worth noting here that hypo-vitaminosis D is prevailing even in Middle Eastern countries such as Lebanon. ${ }^{17,18}$ Reasons for such a high prevalence of the condition include, among others, public fear of risk of skin cancer, traditional clothing and cultural and cosmetic reasons. It is intriguing that the pharmacist, a frontline healthcare provider, was the last in the order of sources of information on vitamin D for both groups of students. This observation calls for more efforts on pharmacists to play a major role in educating the public of the importance of vitamin D.

When asked about the sectors of population who are at high risk of vitamin D deficiency, the majority (75\%) of engineering students selected "others" including infants, children, young adults and pregnant women, while the majority $(51.8 \%)$ of pharmacy students selected the elderly followed by others. Earlier reports indicated that young adults aged 20-39 years are at the highest risk of deficiency. ${ }^{8}$ High incidence of vitamin D deficiency has also been reported for young adults and school children in Middle Eastern countries. ${ }^{19,20}$ Moreover, results of studies from Saudi Arabia, Kuwait, UAE, and Iran revealed that $10-60 \%$ of mothers and $40-80 \%$ of their neonates had undetectable low vitamin D levels (0-25 nmol/l) at delivery. ${ }^{21-24}$ Recommendation by physicians was responsible for $40.4 \%$ of pharmacy and $21 \%$ of engineering students taking vitamin D supplement. Again, more pharmacy (60.6\%) than engineering (49.5\%) students undertook the screening test for vitamin D. We observed strong positive association between age (21-23 years) and the level of knowledge. In general, it seems that despite the reasonable level of knowledge of both groups of students of basic information on vitamin $\mathrm{D}$, a significantly large number of students admitted not having enough information on vitamin $\mathrm{D}$ and the majority prefer to receive brochures of adequate information on the subject.

\section{CONCLUSION}

Taken together our results call for an urgent need for collaborative efforts to increase the awareness of the public to the importance of vitamin $\mathrm{D}$ for health. In universities, a possible intervention should be based on lectures, seminars and workshops directed at all students irrespective of their major. University students represent a large sector of the population in any community and in addition they would convey education messages of information to their families and hence a wider circulation of information on vitamin D can spread across the country. Moreover, pharmacists should actively contribute to public's health education on the importance of vitamin D.

Funding: No funding sources Conflict of interest: None declared

Ethical approval: The study was approved by the Institutional Ethics Committee

\section{REFERENCES}

1. Holon R, Byers M, Walker BR, Summerton C. Environmental and nutritional factors in diseases. Davidson's Principles and Practice of Medicine. In: Walker B, Colledge NR, Ralston S, Penman I, eds. 22nd ed. Edinburgh: Churchill Livingstone; 2014.

2. Holick MF. Evolution, biologic functions, and recommended dietary allowance for vitamin D. In: Holick MF, ed. Vitamin D: physiology, molecular biology and clinical applications. Clifton, NJ: Humana Press; 1999: 1-16.

3. Bischoff HA, Stahelin HB, Urscheler N, Ehrsam R, Vonthein R, Perrig-Chiello P, et al. Muscle strength in the elderly: its relation to vitamin $\mathrm{D}$ metabolites. Arch Phys Med Rehabil. 1999;80(1):54-8. 
4. Hernan MA, Olek MJ, Ascherio A. Geographic variation of MS incidence in two prospective studies of US women. Neurol. 1999;53(8):1711-8.

5. Pittas AG, Harris SS, Stark PC, Dawson-Hughes B. The effects of calcium and vitamin D supplementation on blood glucose and markers of inflammation in non-diabetic adults. Diabetes Care. 2007;30(4):980-6.

6. Holick MF. Vitamin D deficiency. N Engl J Med. 2007;357(3):266-81.

7. Giovannucci E, Liu Y, Hollis BW, Rimm EB. 25Hydroxyvitamin D and risk of myocardial infarction in men: a prospective study. Arch Intern Med. 2008;168(11):1174-180.

8. Whiting SJ, Langlois KA, Vatanparast H, GreeneFinestone LS. The vitamin D status of Canadians relative to the 2011DietaryReference Intakes: an examination in children and adults with and without supplement use. Am J Clin Nutr. 2011;94(1):128-35.

9. Holick MF, Binkley NC, Bischoff-Ferrari HA, Gordon CM, Hanley DA, Heaney RP, et al. Endocrine Society. Evaluation, treatment, and prevention of vitamin D deficiency: an Endocrine Society clinical practice guideline. J Clin Endocrinol Metab. 2011;96(7):1911-30.

10. Cranney A, Horsley T, O'Donnell S, Weiler H, Puil L, Ooi D, et al. Effectiveness and safety of vitamin D in relation to bone health, Evid Rep Technol Assess (Full Rep). 2007;158:1-235.

11. Mawer EB, Davies M. Vitamin D nutrition and bone disease in adults. Rev Endocr Metab Disord. 2001;2(2):153-64.

12. Rizzoli R, Bonjour J. Dietary protein and bone health. J Bone Miner Res. 2004;19(4):527-31.

13. Luqman M, Kousar NA, Abid SM. Prevalence of vitamin-d deficiency in patients presenting with musculoskeletal manifestations in medical OPD of CMH Lahore. J Pak OrthopAssoc. 2012;24:50-6.

14. Chan SP, Scott BB, Sen SS. An Asian viewpoint on the use of vitamin $\mathrm{D}$ and calcium in osteoporosis treatment: physician and patient attitude and beliefs. BMC Musculoskeletal Disorder. 2010;11:248.

15. Uddin R, Huda NH, Jhanker YM, Jesmeen T, Imam $\mathrm{MZ}$, Akter S. Awareness regarding the importance of calcium and vitamin D among the undergraduate pharmacy students in Bangladesh. BMC Res Notes. 2013;6:134.
16. Boland S, Irwin JD, Johnson AM. A survey of university students' vitamin D -related knowledge. J Nutr Educ Behav. 2015;47(1): 99-103.

17. Fuleihan GE. Vitamin D deficiency in the Middle East and its health consequences. In: Holick MF, ed. Vitamin D: physiology, molecular biology, and clinical applications. Clifton, NJ: Humana Press; 2010: 469-494.

18. Gannage-Yared MH, Chemali R, Yaacoub N, Halaby G. Hypovitaminosis D in a sunny country: relation to lifestyle and bone markers. J Bone Miner Res. 2000;15(9):1856-62.

19. Rostand SG. Ultraviolet light may contribute to geographic and racial blood pressure differences. Hypertens. 1997;30:150-6.

20. Salamoun MM, Kizirian AS, Tannous RI, Nabulsi MM, Choucair MK, Deeb ME, et al. Low calcium and vitamin $\mathrm{D}$ intake in healthy children and adolescents and their correlates. Eur J Clin Nutr. 2005;59(2):177-84.

21. Bassir M, Laborie S, Lapillonne A, Claris O, Chappuis MC, Salle BL. Vitamin D deficiency in Iranian mothers and their neonates: a pilot study. Acta Paediatr. 2001;90(5):577-9.

22. Ainy E, Ghazi AAM, Azizi F. Changes in calcium, $25(\mathrm{OH})$ vitamin D3 and other biochemical factors during pregnancy. J Endocrinol Invest. 2006;29(4):303-7.

23. Molla AM, Al Badawi M, Hammoud MS, Molla AM, Shukkur M, Thalib L, et al. Vitamin D status of mothers and their neonates in Kuwait. Pediatr Int. 2005;47(6):649-52.

24. Serenius F, Elidrissy ATH, Dandona P. Vitamin D nutrition in pregnant women at term and in newly born babies in Saudi-Arabia. $\mathbf{J}$ Clin Pathol. 1984;37(4):444-7.

Cite this article as: Sharif SI, Ibrahim S, Mohammad A, Matini G, Sharif RS. Evaluation of knowledge of vitamin $\mathrm{D}$ aspects among pharmacy and engineering students in University of Sharjah, United Arab Emirates. Int J Basic Clin Pharmacol 2019;8:2585-91. 